\title{
Relative Growth Rate of Six Soybean Genotypes Under Iron Toxicity Condition
}

\author{
Heru Kuswantoro ${ }^{1}$ \\ ${ }^{1}$ Indonesian Legume and Tuber Crops Research Institute, Indonesian Agency for Agricultural Research and \\ Development, Indonesia
}

Correspondence: Heru Kuswantoro, Indonesian Legume and Tuber Crops Research Institute, Indonesian Agency for Agricultural Research and Development, Malang, Indonesia. E-mail: herukusw@yahoo.com

\author{
Received: February 11, 2014 Accepted: March 10, 2014 Online Published: March 19, 2014 \\ doi:10.5539/ijb.v6n3p11 \\ URL: http://dx.doi.org/10.5539/ijb.v6n3p11
}

\begin{abstract}
The objective of the research was to study relative growth rate of six soybean genotypes under iron toxicity condition. The design was factorial design, with two factors; arranged in completely randomized design with three replications. The first factor was Fe concentration, consisted of two levels, i.e. (1) 0 ppm Fe and (2) 375 ppm Fe where after 7 days the acidity was not maintain at $\mathrm{pH} 3.5$. The second factor was genotype, consisted of 6 genotypes, i.e. two tolerant genotypes (MLGG 0799 and MLGG 0492), three susceptible genotypes (MLGG 0915, MLGG 0768 and MLGG 0169) and one check swampland tolerant-variety (Lawit). The results showed that genotypes of MLGG 0799 and MLGG 0768 had higher rhizosphere pH levels than other genotypes. MLGG 0492 had potency to self recovery better than other genotypes based on relative growth rate (RGR) of root dry weight, plant height and plant dry weight. MLGG 0492 may have different mechanism than others because this genotype remained to have higher RGR, although it was unable to increase the rhizosphere $\mathrm{pH}$. Under control and Fe treatment conditions, Lawit had no significant difference of RGR of plant dry weight to other susceptible genotypes.
\end{abstract}

Keywords: Iron toxicity, relative growth rate, rhizosphere, soybean

\section{Introduction}

As an essential element for plants, iron ( $\mathrm{Fe}$ ) has many important biological roles in plant metabolic processes (Mehraban et al., 2008), such as photosynthesis and respiration (Connolly \& Guerinot, 2002), and responsible to quantity and quality of plant yield (Celik et al., 2010). However, Fe will be toxic when it is accumulated in a high level (Connolly \& Guerinot, 2002) and mobilized and stockpiled in soil solution (Audebert, 2006). Usually Fe toxicity becomes a major constraint on lowland acid soils, swampy lands, coastal swamps and irrigated lowlands of ultisols and oxisols (Mandal et al., 2004). In Indonesia, swampy lands cover 33.4 million ha; consisting of 20.192 million ha of tidal swamp area and 13.283 million ha of lebak swamp area (Widjaya-Adhi, 1985).

Root has an important role in plant growth because nutrition uptake will be distressed when the root is damage. Fe toxicity causes roots growth termination and unsharpening root tips, and lead plant death in high level of Fe toxicity (Islami \& Utomo, 1995). Beside the root tips, root border cells play an important role in plant resistance to Fe toxicity (Wen et al., 2007). The dosage and time treatment of $\mathrm{Fe}^{2+}$ will affect border cells viability (Xing et al., 2008), and as consequently will decrease root capacity to uptake nutrition as well as to survive. Finaly, Fe toxicity causes inhibition for plant growth and development (Albano \& Miller, 1998; Izaguirre-Mayoral \& Sinclair, 2005; Mehraban et al., 2008; Xing et al., 2008) due to both of toxicity and nutrition uptake disorders.

An adaptive response is required by plant species in a particular rhizosphere environment to perceive changes in the local environment (Walker et al., 2003). Variability in response to Fe toxicity was found not only in inter-species but also in intra-species. There are indications of variability among soybeans (Lin et al., 2000; Izaguirre-Mayoral \& Sinclair, 2005, Kuswantoro et al., 2010), rice (Mandal et al., 2004; Camara, 2006; Diata \& Sahrawat, 2006), and wheat (Setter et al., 2009; Yavas et al., 2012) genotypes in response to Fe concentrations. Under Fe-toxic condition, Fe-tolerant rice cultivars show superior performance partly due to both of avoidance and Fe tolerance (Mandal et al., 2004). On the roots of wetland plants, the formation of iron oxyhydroxide deposits may reduce the amount of iron entering the plant tissues and providing a mechanism for the avoidance 
of toxicity (Batty \& Younger, 2003).

Rhizosphere is a complex environment because roots interact with physical, chemical and biological properties, where rhizosphere processes are affected by structural and functional characteristics of roots (Richardson et al., 2009). The survival of them may be threatened by extreme acidic environments. Hence, to survive and facilitate growth in low $\mathrm{pH}$, plants may actively modify their rhizosphere $\mathrm{pH}$ by extruding $\mathrm{OH}^{-}$and $\mathrm{HCO}_{3}{ }^{-}$(Dakora \& Phillips, 2002). Soybean also can increase the rhizosphere pH (Zhou et al., 2009; Schoninger, 2012) to modify the root environment for root survival and nutrients acquisition. Therefore the alteration of the rhizozphere will affect soybean growth rate under iron toxicity condition.

\section{Materials and Method}

This study was conducted at the screen house of Indonesian Legume and Tuber Crops Research Institute (ILETRI). The design was factorial design, with two factors; was arranged in completely randomized design (CRD) with three replications. The first factor was Fe concentration that consisted of two levels, i.e. (1) $0 \mathrm{ppm}$ Fe (control) and (2) $375 \mathrm{ppm} \mathrm{Fe} \mathrm{(Fe} \mathrm{toxicity} \mathrm{treatment).} \mathrm{The} \mathrm{second} \mathrm{factor} \mathrm{was} \mathrm{genotype} \mathrm{that} \mathrm{consisted} \mathrm{of} 6$ genotypes, i.e. two tolerant genotypes (MLGG 0799 and MLGG 0492), three susceptible genotypes (MLGG 0915, MLGG 0768 and MLGG 0169) and one check tolerant-variety (Lawit). All of plant materials were obtained from ILTRI's germplasm collection. Two hundred seeds of each six soybean genotypes were germinated on sand culture. Five days after germination, seedling were transplanted in aqua culture using styrofoam to make the seedling floating. Two days after transplanting (dat), seedlings were transplanted into $\mathrm{Fe}$ toxicity culture and the control (without Fe toxicity). Every treatment consisted of 10 plants. The $\mathrm{pH}$ was maintained at 3.5 level until 14 dat by adding $\mathrm{HCl}$ when $\mathrm{pH}$ level increased. Seven days after transplanting, the $\mathrm{pH}$ was not cotrolled up to 21 dat. Observations were carried out at 14 and 21 dat for root and hypocotyl length, plant height, root and plant dry weight, to calculate relative growth rate (RGR). The measuring of RGR followed Sitompul and Guritno (1995) as below:

$$
R G R=\frac{\operatorname{Ln} V_{2}-\operatorname{Ln} V_{1}}{T_{2}-T_{1}}
$$

Where: RGR $=$ relative growth rate $\left(\mathrm{g} \cdot \mathrm{g}^{-1} \cdot \mathrm{day}^{-1}\right)$ or $\left(\mathrm{cm} \cdot \mathrm{cm}^{-1} \cdot \mathrm{day}^{-1}\right) ; \mathrm{V}_{1}=$ observed variable at 14 dat; $\mathrm{V}_{2}=$ observed variable at 21 dat; $T_{1}=$ started time $(14$ dat $) ; T_{2}=$ ended time (21 dat).

Data were analyzed using analysis of variance followed by honestly signififant difference (HSD) at level of 5\% for single factor of Fe concentration and Duncan multiple range test (DMRT) at level of 5\% for genotype and interaction between Fe concentration and genotype.

\section{Results and Discusion}

Rhizosphere acidity decreased or the $\mathrm{pH}$ increased as well as the age of the genotypes increased (Table 1). Table 2 described the increasing of rhizosphere $\mathrm{pH}$ during 7 days of the seedling growth measured from 15 dat (day after transplanting). Genotype MLGG 0768 and MLGG 0799 showed the lowest acidity in the rhizosphere (Table 3).

Table 1. Alteration of $\mathrm{pH}$ levels in the rhizosphere by Fe toxicity in various seedling ages

\begin{tabular}{cc}
\hline Seedling age (dat) & $\mathrm{pH}$ of the rhizosphere \\
\hline 15 & $3.49 \mathrm{a}$ \\
16 & $3.57 \mathrm{ab}$ \\
17 & $3.64 \mathrm{abc}$ \\
18 & $3.71 \mathrm{bc}$ \\
19 & $3.79 \mathrm{~cd}$ \\
20 & $3.96 \mathrm{~d}$ \\
21 & $3.98 \mathrm{de}$ \\
\hline Average & 3.73
\end{tabular}

Values followed by the same letter were not significantly different according to DMRT $5 \%$. 
Genotype MLGG 0799 and MLGG 0768 showed the lowest acidity in its rhizosphere presumably because the roots released more ion $\mathrm{OH}^{-}$compared to other genotypes (Table 2) as stated by Suhartini (2004) that there are difference among varieties in excretion of ion $\mathrm{OH}^{-}$. Physiologically, variety excreting more $\mathrm{OH}^{-}$and decreasing acidity would absorb fewer $\mathrm{Fe}$, while variety excreting fewer $\mathrm{OH}^{-}$tended to decreased $\mathrm{pH}$ and absorb more Fe. Sliman (1990) also reported different response between two soybean genotypes, where Hawkeye decreased the $\mathrm{pH}$ of solution while PI-54619-5-1 increased the $\mathrm{pH}$ of solution. Different response to iron toxicity was induced by expression of different gene sets (Connolly \& Guerinot, 2002). Therefore, resistance to Fe toxicity was a rather complex trait in both genetically and physiologically aspects (Shabala, 2010).

Table 2. Alteration of rhizosphere acidity with Fe toxicity of six genotypes

\begin{tabular}{cccccccc}
\hline \multirow{2}{*}{ Genotypes } & \multicolumn{7}{c}{ Seedling age (dat) } \\
\cline { 2 - 8 } & 15 & 16 & 17 & 18 & 19 & 20 & 21 \\
\hline MLGG 0799 & $3.7 \pm 0.31$ & $3.7 \pm 0.42$ & $3.9 \pm 0.56$ & $3.9 \pm 0.67$ & $4.1 \pm 0.7$ & $4.2 \pm 0.78$ & $4.2 \pm 0.78$ \\
MLGG 0492 & $3.4 \pm 0.06$ & $3.5 \pm 0.00$ & $3.5 \pm 0.06$ & $3.6 \pm 0.00$ & $3.7 \pm 0.06$ & $3.8 \pm 0.11$ & $3.9 \pm 0.12$ \\
Lawit & $3.4 \pm 0.00$ & $3.5 \pm 0.06$ & $3.5 \pm 0.06$ & $3.5 \pm 0.06$ & $3.7 \pm 0.06$ & $3.7 \pm 0.01$ & $3.7 \pm 0.06$ \\
MLGG 0915 & $3.4 \pm 0.06$ & $3.5 \pm 0.00$ & $3.5 \pm 0.06$ & $3.6 \pm 0.06$ & $3.7 \pm 0.06$ & $3.8 \pm 0.06$ & $3.8 \pm 0.06$ \\
MLGG 0768 & $3.5 \pm 0.12$ & $3.7 \pm 0.06$ & $3.8 \pm 0.06$ & $3.9 \pm 0.11$ & $4.0 \pm 0.16$ & $4.4 \pm 0.21$ & $4.4 \pm 0.26$ \\
MLGG 0169 & $3.5 \pm 0.06$ & $3.5 \pm 0.06$ & $3.6 \pm 0.11$ & $3.7 \pm 0.06$ & $3.7 \pm 0.1$ & $3.8 \pm 0.06$ & $3.9 \pm 0.12$ \\
\hline
\end{tabular}

Table 3. Average of rhizosphere acidity with Fe toxicity of six genotypes

\begin{tabular}{cc}
\hline Genotypes & pH of the rhizosphere \\
\hline MLGG 0799 & $3.97 \mathrm{~b}$ \\
MLGG 0492 & $3.63 \mathrm{a}$ \\
Lawit & $3.58 \mathrm{a}$ \\
MLGG 0915 & $3.62 \mathrm{a}$ \\
MLGG 0768 & $3.95 \mathrm{~b}$ \\
MLGG 0169 & $3.67 \mathrm{a}$ \\
\hline Average & 3.73
\end{tabular}

Values followed by the same letter were not significantly different according to DMRT $5 \%$.

Treatment of Fe significanlty affected RGR of hypocotyl length and root dry weight. RGR of those two characters were significanlty different among genotypes. RGR of hypocotyl length after the termination of $\mathrm{HCl}$ adding was higher than the control. It was assumed that in control $(0 \mathrm{ppm} \mathrm{Fe})$ the seeddlings lack of Fe causing inhibition on chlorophyl formation. This inhibition caused decreasing photosyntesis, and consequently also decreasing the plant shoot growth. Merhaban et al. (2008) also reported a similar result that there was a decreasing shoot dry weight due to the lack of Fe.

RGR of root dry weight in Fe toxicity condition after the termination of $\mathrm{HCl}$ adding was lower than the control (Table 4). It occured because in Fe toxicity condition, the plants lack of essential nutrition such as $\mathrm{P}, \mathrm{K}, \mathrm{Ca}$, and $\mathrm{Mg}$. Lack of $\mathrm{P}$ caused root growth inhibition, while lack of Ca caused root branches shorter and fragile (Islami \& Utomo, 1995). In anaerobic condition, the lower root dry weight also affected by nutrient defficiency (Steffens et al., 2005). 
Table 4. Average of RGR of hypocotyl length and root dry weight in two Fe levels

\begin{tabular}{ccc}
\hline Characters & \multicolumn{2}{c}{ RGR } \\
\cline { 2 - 3 } & 0 ppm of Fe & 375 ppm of Fe \\
\hline Hypocotyl length $\left(\mathrm{cm}^{\circ} \mathrm{cm}^{-1} \cdot\right.$ day $\left.^{-1}\right)$ & $0.009 \mathrm{a}$ & $0.019 \mathrm{~b}$ \\
Root dry weight $\left(\mathrm{g} \cdot \mathrm{g}^{-1} \cdot \mathrm{day}^{-1}\right)$ & $0.084 \mathrm{~b}$ & $0.053 \mathrm{a}$
\end{tabular}

Values in the same row followed by the same letter were not significantly different according to HSD 5\%.

Root dry weight is the most important character in evaluation of plant resistance to Fe toxicity because the direct effect of Fe toxicity occurs on root. Table 5 showed that MLGG 0492 had the highest RGR of root dry weight among the genotypes. Lawit as a tolerant check variety also showed RGR of root dry weight lower than MLGG 0492. Kuswantoro et al. (2010) used Lawit as check tolerant variety with four other varieties and reported that Lawit had the highest selection index value, where the RGR of root dry weight became a main character. Therefore, the genotype with RGR of root dry weight higher than Lawit could be classified as tolerant genotype. MLGG 0492 was more tolerant than other genotypes, including Lawit, this genotype can be used as gene resource for development of soybean tolerant to Fe toxicity.

Table 5. RGR of root dry weight of six soybean genotypes

\begin{tabular}{|c|c|}
\hline Genotypes & Root dry weight $\left(\mathrm{g} \cdot \mathrm{g}^{-1} \cdot\right.$ day $\left.^{-1}\right)$ \\
\hline MLGG 0799 & $0.062 \mathrm{a}$ \\
\hline MLGG 0492 & $0.113 \mathrm{~b}$ \\
\hline Lawit & $0.054 \mathrm{a}$ \\
\hline MLGG 0915 & $0.061 \mathrm{a}$ \\
\hline MLGG 0768 & $0.050 \mathrm{a}$ \\
\hline MLGG 0169 & $0.070 \mathrm{a}$ \\
\hline
\end{tabular}

Values followed by the same letter were not significantly different according DMRT 5\%.

Interaction between Fe concentration and genotype significantly affected RGR of plant height. MLGG 0799 and Lawit under control condition ( $0 \mathrm{ppm}$ of $\mathrm{Fe}$ ) showed the highest RGR of plant height, while after $\mathrm{HCl}$ adding termination (14 dat) MLGG 0492 showed the highest RGR of plant height and not significantly different to MLGG 0768 and Lawit (Table 6). The interaction of RGR of plant height was caused by the differences response of the genotypes to $\mathrm{Fe}$ toxicity. Different response of genotypes to Fe toxicity was also reported by some researchers as Aung (2006) in rice and Albano et al. (1996) in marigold.

Table 6. RGR of plant height of six soybean genotypes

\begin{tabular}{ccc}
\hline \multirow{2}{*}{ Genotypes } & \multicolumn{2}{c}{ Plant height $\left(\mathrm{cm}^{-1} \cdot \mathrm{cm}^{-1} \cdot \mathrm{day}^{-1}\right)$} \\
\cline { 2 - 3 } & $0 \mathrm{ppm}$ of Fe & $375 \mathrm{ppm}$ of Fe \\
\hline MLGG 0799 & $0.044 \mathrm{~d}$ & $0.012 \mathrm{abc}$ \\
MLGG 0492 & $0.006 \mathrm{ab}$ & $0.039 \mathrm{~cd}$ \\
Lawit & $0.019 \mathrm{abcd}$ & $0.034 \mathrm{bcd}$ \\
MLGG 0915 & $0.009 \mathrm{ab}$ & $0.012 \mathrm{abc}$ \\
MLGG 0768 & $0.010 \mathrm{ab}$ & $0.026 \mathrm{abcd}$ \\
MLGG 0169 & $0.004 \mathrm{a}$ & $0.010 \mathrm{ab}$ \\
\hline
\end{tabular}

Values followed by the same letter were not significantly different according DMRT 5\%.

Genotype MLGG 0492 had potency to self recovery better than the other genotypes (Table 7). It was shown on 
RGR of root dry weight, plant height and shoot dry weight which were higher than other the genotypes, even though the level of rhizosphere acidity was higher than genotypes of MLGG 0799 and MLGG 0768. The inability of MLGG 0492 to increase the rhizosphere $\mathrm{pH}$ was assumed that the root of this genotype excreted fewer $\mathrm{OH}^{-}$, therefore the $\mathrm{pH}$ remain low. It leads to assume that tolerance mechanism of MLGG 0492 under Fe toxicity was not releasing ion $\mathrm{OH}^{-}$or improvement environmental $\mathrm{pH}$, but through enzymatic process; as stated by Marschner (1995) that plant responded unfavourble environment condition by two ways, i.e. with excretion $\mathrm{OH}^{-}$or eliminate $\mathrm{Fe}$ through rhizosphere oxidation and excretion of $\mathrm{Fe}$ in large amount with enzyme aid or deactivating $\mathrm{Fe}$ in plant organs.

Table 7. RGR of plant dry weight of six soybean genotypes

\begin{tabular}{ccc}
\hline \multirow{2}{*}{ Genotypes } & \multicolumn{2}{c}{ Plant dry weight $\left({\mathrm{g} \cdot \mathrm{g}^{-1} \cdot \text { day }}^{-1}\right)$} \\
\cline { 2 - 3 } & $0 \mathrm{ppm}$ & $375 \mathrm{ppm}$ \\
\hline MLGG 0799 & $0.062 \mathrm{a}$ & $0.020 \mathrm{a}$ \\
MLGG 0492 & $0.115 \mathrm{~b}$ & $0.240 \mathrm{c}$ \\
Lawit & $0.044 \mathrm{a}$ & $0.056 \mathrm{a}$ \\
MLGG 0915 & $0.066 \mathrm{a}$ & $0.019 \mathrm{a}$ \\
MLGG 0768 & $0.110 \mathrm{~b}$ & $0.029 \mathrm{a}$ \\
MLGG 0169 & $0.055 \mathrm{a}$ & $0.027 \mathrm{a}$
\end{tabular}

Values followed by the same letter were not significantly different according DMRT 5\%.

\section{Conclusion}

Relative growth rate of six soybean genotypes to Fe toxicity were different due to the genetic constitutions. The genetic constitution differences also affected solution culture medium properties, especially the $\mathrm{pH}$ of the solution culture. Genotypes of MLGG 0799 and MLGG 0768 showed higher rhizosphere pH than other genotypes. Increasing rhizosphere $\mathrm{pH}$ considered as one of the plants mechanisms to tolerate and to recover from the stress condition. MLGG 0492 had a potency to self recovery better than the other genotypes based on the RGR of root dry weight, plant height and plant dry weight; and considered having different mechanism than other genotypes. Even though Lawit was released as tolerant variety in tidal swampland, in this research Lawit had no significant difference to other susceptible genotypes under control and Fe treatment conditions for RGR of plant dry weight trait; it is suggested that Lawit was more adaptive in optimal condition.

\section{Acknowledgements}

This study was funded by the State Ministry of Research and Technology of Republic of Indonesia. Special thank to Ms. Wasiaturrohmah for the assistance in the research.

\section{References}

Albano, J. P., \& Miller, W. B. (1998). Marigold cultivar vary in susceptibility to Fe toxicity. Hort. Sci., 33, 1180-1182.

Albano, J. P., Miller, W. B., \& Hallbrooks, M. C. (1996). Iron toxicity stress causes bronze speckle, a specific physiological disorder of marigold (Tagetes erecta L.). J. Amer. Soc. Hort. Sci., 121, 430-437.

Audebert, A. (2006). Diagnosis of risk and approaches to iron toxicity management in lowland rice farming. In A. Audebert, L. T. Narteh, P. Kiepe, D. Millar \& B. Beks (Eds.), Iron Toxicity in Rice-based Systems in West Africa (pp. 6-17). Africa Rice Center (WARDA).

Aung, T. (2006). Physiological mechanisms of iron toxicity tolerance in lowland rice. Institute of Crop Science and Resource Conservation (INRES). Department of Plant Nutrition. Faculty of Agriculture Rheinische Friedrich-Wilhelms-Universität zu Bonn. Thesis. p. 76.

Batty, L. C., \& Younger, P. L. (2003). Effects of external iron concentration upon seedling growth and uptake of fe and phosphate by the common reed, Phragmites australis (Cav.) Trin ex. Steudel. Annals of Botany, 92, 801-806. http://dx.doi.org/10.1093/aob/mcg205

Camara, A. K. (2006). Testing and developing tolerant rice varieties to iron toxicity in lower guinea (Cra Kilissi 
and Koba). In A. Audebert, L. T. Narteh, P. Kiepe, D. Millar \& B. Beks (Eds.), Iron Toxicity in Rice-based Systems in West Africa (pp. 64-74). Africa Rice Center (WARDA).

Celik, H., Asik, B. B., Gurel, S., \& Katkat, A. V. (2010). Effect of potassium and iron on macro element uptake of maize. Zemdirbyste Agriculture, 97, 11-22.

Connolly, E. L., \& Guerinot, M. L. (2002). Iron stress in plants. Genome Biology, 3, 1024.1-1024.4. Retrieved June 1, 2012, from http://genomebiology.com/2002/3/8/reviews/1024.1

Dakora, F. D., \& Phillips, D. A. (2002). Root exudates as mediators of mineral acquisition in low-nutrient environments. Plant and Soil, 245, 35-47.

Diata, S., \& Sahrawat, R. K. (2006). Iron toxicity of rice in west africa:screening tolerant varieties and the role of N, P, K and Zn. In A. Audebert, L. T. Narteh, P. Kiepe, D. Millar \& B. Beks (Eds.), Iron Toxicity in Rice-based Systems in West Africa (pp. 75-81). Africa Rice Center (WARDA).

Islami, T., \& Utomo, W. H. (1995). Hubungan Tanah, Air dan Tanaman. Semarang. IKIP Semarang Press.

Izaguirre-Mayoral, M. L., \& Sinclair, T. R. (2005). Soybean genotypic difference in growth, nutrient accumulation and ultrastructure in response to manganese and iron supply in solution culture. Annals of Botany, 96, 149-158. http://dx.doi.org/10.1093/aob/mci160

Kuswantoro, H., Wijanarko, A., Setyawan, D., William, E., Dadang, A., \& Mejaya, I. M. J. (2010). Soybean germplasms evaluation for acid tidal swamp tolerance using selection index. International Journal of Plant Biology, 1, 56-60. http://dx.doi.org/10.4081/pb.2010.e11

Lin, S. F., Grant, D., Cianzio, S., \& Shoemaker, R. (2000). Molecular characterization of iron eficiency chlorosis in soybean. Journal of Plant Nutrition, 23, 1929-1939. http://dx.doi.org/10.1080/01904160009382154

Mandal, A. B., Basu, A. K., Roy, B., Sheeja, T. E., \& Roy, T. (2004). Genetic management for increased tolerance to aluminium and iron tocixities in rice - A review. Indian Journal of Biotechnology, 3, 359-368.

Marschner, H. (1995). Mineral nutrition of higher plants. Functions of mineral nutrients: Micronutrients: Iron (pp. 313-323). London: Academic Press.

Mehraban, P., Zadeh, A. A., \& Sadeghipour, H. R. (2008). Iron toxicity in rice (Oryza sativa L.) under different potassium nutrition. Asian Journal of Plant Sci., 7, 251-259.

Richardson, A. E., Barea, J. M., McNeill, A. M., \& Prigent-Combaret, C. (2009). Acquisition of phosphorus and nitrogen in the rhizosphere and plant growth promotion by microorganisms. Plant Soil, 321, 305-339. http://dx.doi.org/10.1007/s11104-009-9895-2

Schoninger, E. L., Gatiboni, L. C., \& Ernanibrachiaria, P. R. (2012). Rhizosphere pH and phosphorus forms in an Oxisol cultivated with soybean, grass, millet and sorghum. Sci. Agric., 69, 259-264. http://dx.doi.org/10.1590/S0103-90162012000400004

Setter, T. L., Waters, I., Sharma, S. K., Singh, K. N., Kulshreshtha, N., Yaduvanshi, N. P. S., ... Cakir, M. (2009). Review of wheat improvement for waterlogging tolerance in Australia and India: the importance of anaerobiosis and element toxicities associated with different soils. Annals of Botany, 103, 221-235. http://dx.doi.org/10.1093/aob/men137

Shabala, S. (2010). Physiological and cellular aspects of phytotoxicity tolerance in plants: the role of membrane transporters and implications for crop breeding for waterlogging tolerance. New Phytologist. http://dx.doi.org/10.1111/j.1469-8137.2010.03575.x

Sitompul, S. M., \& Guritno, B. (1995). Analisis Pertumbuhan Tanaman (p. 412). Yogyakarta: Gadjah Mada University Press.

Sliman, Z. T. (1990). Effect of zinc on iron-stress-response mechanism of two soybean genotypes. J. King Saud Univ. Agric. Sci., 2, 61- 69.

Steffens, D., Hütsch, B. W., Eschholz, T., Lošák, T., \& Schubert, S. (2005). Waterlogging may inhibit plant growth primarilyby nutrient deficiency rather than nutrient toxicity. Plant Soil Environ., 51, 545-552.

Suhartini, T. (2004). Perbaikan varietas padi untuk lahan keracunan Fe. Buletin Plasma Nutfah, 10, 1-11.

Walker, T. S., Bais, H. P., Grotewold, E., \& Vivanco, J. M. (2003). Root exudation and rhizosphere biology. Plant Physiology, 132, 44-51. http://dx.doi.org/10.1104/pp.102.019661

Wen, F. S., VanEtten, H. D., Tsaprailis, G., \& Hawes, M. C. (2007). Extracellular proteins in pea root tip and 
border cell exudates. Plant Physiol., 143, 773-783. http://dx.doi.org/10.1104/pp.106.091637

Widjaja-Adhi, I. P. G. (1985). Pengapuran tanah masam untuk kedelai. In S. D. Somaatmadja, M. Ismunadji, Sumarno, M. Syam, S. O. Manurung \& dan Yuswadi (Eds.), Kedelai (pp. 171-188). Bogor: Pusat Penelitian dan Pengembangan Tanaman Pangan.

Xing, C. H., Zhu, M. H., Cai, M. Z., Liu, P., Xu, G. D., \& Wu, S. H. (2008). Developmental characteristics and response to iron toxicity of root border cells in rice seedlings. Journal Zhejiang Univ. Sci., B9, 261-264. http://dx.doi.org/10.1631/jzus.B0710627

Yavas, I., Unay, A., \& Aydin. (2012). The waterlogging tolerance of wheat varieties in western of Turkey. The Scientific World Journal, 2012,1-7. http://dx.doi.org/10.1100/2012/529128

Zhou, L. L., Cao, J., Zhang, F. S., \& Li, L. (2009). Rhizosphere acidification of faba bean, soybean and maize. Science of the Total Environment, 407, 4356-4362. http://dx.doi.org/10.1016/j.scitotenv.2009.02.006

\section{Copyrights}

Copyright for this article is retained by the author(s), with first publication rights granted to the journal.

This is an open-access article distributed under the terms and conditions of the Creative Commons Attribution license (http://creativecommons.org/licenses/by/3.0/). 